DOI: https://doi.org/10.15407/techned2019.01.0 $\underline{2} \underline{5}$

\title{
SOURCE OF THE STABILIZED DISCHARGE CURRENT IN CARBON-CONTAINING GASES WITH FREQUENCY-PARAMETRIC REGULATION
}

Journal

Publisher

ISSN

Issue

Pages
Tekhnichna elektrodynamika

Institute of Electrodynamics National Academy of Science of Ukraine 1607-7970 (print), 2218-1903 (online)

No 1, 2019 (January/February)

$25-28$

\section{Authors}

\section{D.V. Vinnychenko*, N.S. Nazarova ${ }^{\star \star}$}

Institute of Pulse Processes and Technologies, Bogoyavlensky, 43 A, Mykolaiv, 54018,Ukraine, e-mail: yuon@ied.org.ua

* ORCID ID : http://orcid.org/0000-0002-8894-860X

** ORCID ID : http://orcid.org/0000-0001-5506-750X

\section{Abstract}

The combined method of frequency-parametric regulation of the stabilized current of the power source is developed on the basis of the resonant inverter for real-time providing of the optimal value of the discharge current during the change of the length of the inter-electrode gap. 
According to this method, to provide a given output current stabilization factor, an automatic transition from the continuous current control is performed by changing the frequency of the inverter to the discrete regulation of the natural frequency of the resonant circle due to the switching of the inductors. The usage of this method ensures current stabilization up to $99 \%$ in the case of the active linear load and $95 \%$ in the case of the electro-discharge load. References 12 , figures 3 .

Key words: power supply, stabilized current, frequency-parametric regulation, resonant inverter, optimal discharge current.

Received: 02.03 .2018

Accepted: 11.05 .2018

Published: 10.01.2019

\section{References}

1. Shcherba A.A., Podoltsev O.D., Kucheriava I.M., Ushakov V.I. Computer Modeling of Electrothermal Processes and Thermomechanical Stress at Induction Heating of Moving Copper Ingots. Tekhnichna Elektrodynamika. 2013. No 2. Pp. 10-18. (Rus)

2. Kuskova N.I., Dubovenko K.V., Petrichenko S.V., Tsolin P.L., Chaban S.O. Electrodischarge Technology and Equipment to Produce New Carbon Nanomaterials. Surface Engineering and Applied Electrochemistry 2013. Vol. 49. No 3. Pp. 35-42. DOI:

https://doi.org/10.3103/S1068375513030095

3. Shcherba A.A., Kosenkov V.M., Bychkov V.M. Mathematical closed model of electric and magnetic fields in the discharge chamber of an Electrohydraulic installation. Surface engineering and applied electrochemistry.

2015. Vol. 51. No. 6. Pp. 581-588. 
4. Shcherba A.A., Suprunovska N.I., Ivaschenko D.S., Beletsky O.A. Prosesses of energy exchange between nonlinear and linear links of electric equivalent circuit of supercapacitors. Te khnicna elektrodynamika .2015. No 5. Pp. 3-11. (Rus).

5. Shcherba A.A., Suprunovska N.I., Ivaschenko D.S. Modeling of Nonlinerial Resistence of Electro-Spark Load Taking into Account its Changes During Discharge Current Flowing in the Load and et Zero Current in it. Tekhnicna elektrodynamika. 2014. No 5. Pp. 23-25. (Rus).

6. Vinnychenko D.V. Influence of electrical parameters of high-voltage electrical discharge installations of nanocarbon synthesis on their productivity and specific energy consumption. Tek hnichna elektrodynamika

. 2016. No 4. Pp. 95-97. (Ukr.).

7. Boguslavskiy L.Z., Vinnychenko D.V., Nazarova N.S. Installation for obtaining carbon nanomaterials. Patent of Ukraine 113323, 2017 (Ukr.).

8. Vinnychenko D.V., Nazarova N.S. Development of control principles of regime parameters of the electrical system for electro-discharge synthesis of carbon nanomaterials. Visnyk NTU KhPI . 2015. No12(1121). Pp. 292-297. (Ukr.).

9. Pavlov G., Vinnichenko I., Pokrovskiy M. Research of the interrelationship between the frequency converter on the basis of the resonant inverter with nonlinear control power unit parameters and its load. IEEE First Ukraine Conference on Electrical and Computer Engineering (UKRCON). 2017. Pp. 554-559. DOI: https://doi.org/10.1 109/UKRCON.2017.8100300

10. Pavlov G., Obrubov A., Vinnichenko I. The linearized dynamic model of the series resonant converter for small signals. IEEE $2^{\text {nd }}$ International Conference on Intelligent Energy and Power Systems

(IEPS), 2016. Pp. 221-225.

11. Zarri, L., Mengoni, M., Toni, A. and Ojo, J.O. Range of the Linear Modulation in Matrix Converters. IEEE Trans. On Power Electronics. 2014. Vol. 29. No 6. Pp. 3166-3178. DOI: http s://doi.org/10.1109/TPEL.2013.2274285

12. Nguyen, P.-K., Sungho J., Berkowitz A.E. MnBi particles with high energy density made by spark erosion. J. Appl. Phys. 2014. Vol. 115. Iss. 17. Pp. 17A756-1. 